\title{
ANALYSIS OF NORMAL AND MUTANT FORMS OF HUMAN ADENOSINE DEAMINASE - A REVIEW
}

\author{
Peter E. DADDONA and William N. KELLEY \\ Departments of Internal Medicine and Biological Chemistry, Human Purine Research Center, University \\ of Michigan Medical School, Ann Arbor, Michigan 48109
}

(Received September 10, 1979)

\section{Summary}

A deficiency of the enzyme adenosine deaminase is associated with an autosomal recessive form of severe combined immunodeficiency disease in man. The molecular forms of the normal human enzyme have now been well characterized in an effort to better understand the nature of the enzyme defect in affected patients.

In some human tissues adenosine deaminase exists predominantly as a small molecular form while in other tissues a large form composed of adenosine deaminase (small form) and an adenosine deaminase-binding protein predominates. The small form of the enzyme purified to homogeneity by antibody affinity chromatography is a monomer of native molecular weight of 37,600. The adenosine deaminase-binding protein, purified by adenosine deaminase affinity chromatography, appears to be a dimer of native molecular weight 213,000 and contains carbohydrate. Based on direct binding measurements, chemical cross-linking studies and sedimentation equilibrium analyses, small form adenosine deaminase has been shown to combine with purified binding protein in a molar ratio of $2: 1$ respectively to produce the large form adenosine deaminase.

Reduced, but widely ranging levels of adenosine deaminating activity, have been reported in various tissues of adenosine deaminase deficient patients. Further, the characteristics of this residual enzyme activity have been analyzed immunochemically to substantiate genetic heterogeneity in this disorder.
While many types of immunodeficiency are currently recognized in man, in most cases the molecular defect is unknown. The discovery of a deficiency of the enzyme, adenosine deaminase, ADA, (EC 3.5.4.4), in some patients with severe combined immunodeficiency disease represented an early clue to the pathogenesis of immune dysfunction at the molecular level ${ }^{1-4}$. Affected patients with markedly reduced levels of ADA exhibit a defect of both cellular and humoral immunity characterized clinically by severe recurrent infections with a fatal outcome if untreated. Attempts to elucidate the nature of the genetic mutation(s) leading to the reduction of ADA activity in these immunodeficient patients have been complicated in part by an incomplete understanding of the nature of ADA in normal tissues. In this review we will consider the structural characteristics of the normal and mutant forms of ADA as they are currently understood.

\section{Molecular Heterogeneity}

Studies of ADA from a variety of normal human tissues have provided evidence for substantial molecular heterogeneity. The enzyme in erythrocytes has been reported to have a molecular weight in the range of 31,000 to $38,000^{5-8}$ and to exhibit genetically determined polymorphism detectable by electrophoresis ${ }^{5}$. In other normal human tissues, two additional molecular forms of the enzyme with apparent molecular weights of 280,000 and 440,000 have 
been described ${ }^{9}$. In addition, electrophoretically distinct isozymes of ADA characteristic for a given tissue have been reported. These observations led EDwARDS, et al. ${ }^{9}$ to suggest that the small form and large forms of the enzyme were coded for by different genes.

The relationship between the molecular and electrophoretic forms of ADA became better understood with the observation that a specific protein termed "conversion factor" could apparently convert the small molecular form of ADA into the large molecular form ${ }^{10}$. Furthermore, it was observed that a patient with ADA deficiency and severe combined immunodeficiency disease lacked both the small and the large form of ADA activity in all tissues suggesting that both forms of the enzyme were coded for by the same structural gene ${ }^{11}$. This finding was supported by the autosomal assignment of ADA exclusively to chromosome $20^{12}$. Finally, the addition of normal small form erythrocyte ADA to various tissue extracts from an ADA deficient patient led to the production of the corresponding, characteristic large "tissue specific" electrophoretic form of the enzyme. These data further supported the one gene hypothesis for ADA and demonstrated the presence of "conversion factor(s)" in a variety of human tissues ${ }^{13}$.

In recent studies in our laboratory, we have examined the nature of the multiple molecular forms of ADA in normal human tissues. In some tissues, e.g. stomach, spleen and small intestine, ADA exists exclusively as the small molecular weight form $(\mathrm{Mr}=36,000)$ while in other tissues, e.g. lung and kidney, the large molecular weight form $(\mathrm{Mr}=298,000)$ predominates $^{14}$. In general, the small form ADA predominates in tissue extracts exhibiting high enzyme specific activity and no detectable "conversion activity" while the large form of the enzyme predominates in tissue extracts exhibiting lower enzyme specific activities and abundant "conversion activity"

An examination of the subcellular distribution of ADA in human leucocyte preparations has indicated that the majority of the ADA activity is soluble $(100,000 \times \mathrm{g}$ fraction) while approximately $2 \%$ of the total activity appeared to be particulate $(6,000 \times \mathrm{g}$ fraction) suggesting that at least a small fraction of ADA is membrane associated $^{14}$. The characteristics of the putative membrane associated ADA and its possible significance have not been explored further. However, examination of the soluble molecular species of ADA has shown that both forms of the enzyme are interconvertible. Under denaturing conditions, the large form ADA can be converted to the small form of the enzyme with release of the "conversion factor". The small form ADA can be converted to the large form of the enzyme in the presence of tissue extracts containing the ADA "conversion factor"14.

We have purified both human small form ADA and the ADA "conversion factor" to homogeneity in order to further examine their characteristics and the nature of their association.

\section{Nature of Small Form Ademosine Deaminase}

The small form of human ADA was purified from erythrocytes to apparent homogeneity using antibody affinity chromatography ${ }^{8}$. As shown in Table 1 , the enzyme was purified 800,000 -fold from crude hemolysate to a final specific activity of $538 \mu \mathrm{mol} / \mathrm{min} / \mathrm{mg}$. The key step in this purification scheme was the use of anti-calf ADA antibody affinity chromatography. To our advantage, antiserum produced against commercially available calf ADA crossreacted with the human enzyme, allowing us to use this highly selective interaction as part of our initial purification scheme.

Native polyacrylamide gel electrophoresis of this highly pure preparation revealed that the 3 major electrophoretic forms of ADA copurified using this isolation technique (Fig. 1A). Sodium dodecyl sulfate (SDS) polyacrylamide gel electrophoresis of this purified preparation revealed one major protein band by Coomassie stain (Fig. 1B) indicating that the electrophoretically different forms of ADA were of the same molecular size. The apparent subunit molecular weight calculated from SDS gels $(\mathrm{Mr}=41,700)$ agreed well with the native molecular weight calculated from the $S_{20, w}$ and Stokes radius $(\mathrm{Mr}=37,600)$ and sedimentation equilibrium analysis $(\mathrm{Mr}=37,500)$, suggesting the small form of enzyme to be monomeric ${ }^{8,15}$.

The highly purified small form ADA was estimated to have less than $10 \%$ carbohydrate content based on a periodic acid-Schiff stain. 
Table 1

Purification of human erythrocyte adenosine deaminase

\begin{tabular}{|c|c|c|c|c|c|c|}
\hline Step & $\begin{array}{l}\text { Volume } \\
\mathrm{ml}\end{array}$ & $\begin{array}{c}\text { Total activity } \\
\mathrm{nmol} / \mathrm{min} \times 10^{5}\end{array}$ & $\begin{array}{c}\text { Total protein } \\
\text { mg }\end{array}$ & $\begin{array}{c}\text { Specific activity } \\
\mathrm{nmol} / \mathrm{min} / \mathrm{mg}\end{array}$ & $\begin{array}{l}\text { Purification } \\
\text {-fold }\end{array}$ & $\begin{array}{c}\text { Recovery } \\
\%\end{array}$ \\
\hline $\begin{array}{l}\text { Crude hemolysate } \\
\text { diluted } 1: 3\end{array}$ & 12,672 & 10.2 & $1.52 \times 10^{6}$ & 0.673 & 1 & 100 \\
\hline $\begin{array}{l}\text { 1. pH adjust } 5.8 \\
\text { 2. CM-Sephadex }\end{array}$ & 13,526 & 10.2 & $1.16 \times 10^{6}$ & 0.881 & 1.3 & 100 \\
\hline batch treatment & 12,626 & 8.78 & $3.53 \times 10^{4}$ & 24.9 & 37 & 86 \\
\hline $\begin{array}{l}\text { 3. } 0-60 \%\left[\mathrm{NH}_{4}\right]_{2} \mathrm{SO}_{4} \\
\text { 4. Affinity }\end{array}$ & 362 & 8.22 & $1.21 \times 10^{4}$ & 67.5 & 100 & 80 \\
\hline chromatography & 0.5 & 3.63 & 0.675 & 538,400 & 800,000 & 35 \\
\hline
\end{tabular}

(from Reference 8).

Further, the carbohydrate portion of small form ADA showed a specific reaction with lotus lectin indicating the presence of a terminal L-fucose residue on the molecule ${ }^{8}$. Nevertheless the chemical, or structural differences, or both, responsible for the three electrophoretic forms of human small form ADA remain to be established.

The purified small form ADA has a broad $\mathrm{pH}$ optimum from 6 to 8 , exhibits a $\mathrm{Km}$ for adenosine of $52 \mu \mathrm{M}$, a $\mathrm{Ki}$ for inosine of $700 \mu \mathrm{M}$, a Stokes radius of $24 \AA$ and an $S_{20, w}$ of $3.8 \times 10^{-13 \mathrm{~s}}$. These properties were found to be identical to those of impure preparations of the

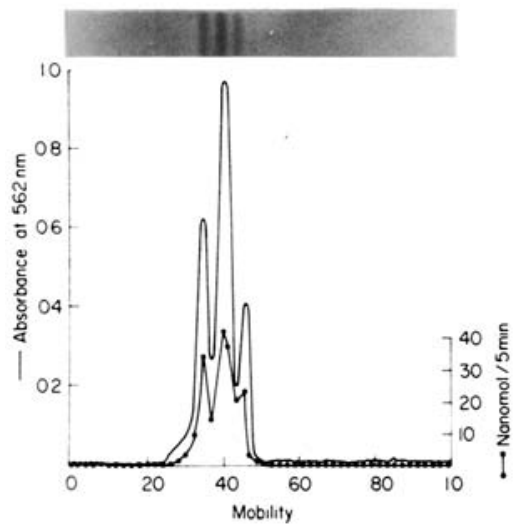

Fig. 1. Polyacrylamide gel electrophoresis of purified erythrocyte ADA. A. Native 5\% polyacrylamide gel, $\mathrm{pH} 8.3$. One gel was stained with Coomassie blue and scanned at $562 \mathrm{~nm}$ while a companion gel was sliced and assayed for enzyme activity. B. SDS-10\% polyacylamide gel stained with Coomassie blue (from reference 8 ). enzyme from several different tissue sources ${ }^{8,14}$. The selected compounds, AMP, dAMP, cAMP, ADP, dADP, ATP, dATP, cytosine, cytidine, CMP, dCMP, CDP, dCDP, CTP and dCTP and $S$-adenosylhomocysteine had no inhibitory affect on the highly purified ADA, while adenine and 6-methylmercaptopurine ribonucleoside had a marked inhibitory effect ${ }^{8}$.

SCHRADER et al. ${ }^{7}$ have also purified human erythrocyte $\mathrm{ADA}$ to homogeneity utilizing a purification scheme different from ours. The key step in their procedure involved an adenosine Sepharose affinity column technique. The reported molecular properties of purified erythrocyte $\mathrm{ADA}$ isolated by their method were similar to those described above.

\section{Nature of the Adenosine Deaminase-Binding Protein ("Conversion Factor")}

Our initial studies were designed to characterize the role of the "conversion factor" in converting the small form ADA to the large molecular form of the enzyme. The apparent conversion process was found to proceed almost equally as well at $37^{\circ} \mathrm{C}$ or $4{ }^{\circ} \mathrm{C}$ and was associated with loss of "converting activity"14. Further, under mild denaturing conditions, the large form of the enzyme yielded the small form ADA and some detectable "converting activity"14. These data suggested a non-enzymatic process whereby the "converting factor" might be binding directly to small form ADA leading to the synthesis of large form. Indeed, following these initial studies, we demonstrated that "conversion factor" activity in human kidney would 
Table 2

Purification of human adenosine deaminase binding protein

\begin{tabular}{|c|c|c|c|c|c|c|}
\hline Step & $\begin{array}{l}\text { Volume } \\
\mathrm{ml}\end{array}$ & $\begin{array}{c}\text { Total activity } \\
\mu \mathrm{mol} / \mathrm{min}\end{array}$ & $\begin{array}{c}\text { Total protein } \\
\mathrm{mg}\end{array}$ & $\begin{array}{c}\text { Specific activity } \\
\mu \mathrm{mol} / \mathrm{min} / \mathrm{mg}\end{array}$ & $\begin{array}{l}\text { Purification } \\
\text {-fold }\end{array}$ & $\begin{array}{c}\text { Recovery } \\
\%\end{array}$ \\
\hline \multicolumn{7}{|l|}{ 1. Crude Kidney } \\
\hline Supernatant & 520 & 823 & 12,776 & 0.064 & 1 & 100 \\
\hline \multicolumn{7}{|l|}{ 2. DEAE-Cellulose } \\
\hline Chromatography & 146 & 559 & 2,800 & 0.20 & 3.1 & 68 \\
\hline \multicolumn{7}{|l|}{ 3. Affinity Chroma- } \\
\hline tography & 1.9 & 245 & 2.27 & 108 & 1,687 & 30 \\
\hline
\end{tabular}

(from Reference 16).

bind to small form ADA covalently linked to Sepharose gel and that this binding activity could be eluted from the column under mild denaturing conditions. Since this ADA-binding factor was further shown to be a protein, we have adopted the more appropriate term ADAbinding protein. To further characterize this ADA-binding protein, we have purified the protein to homogeneity and then studied its properties and the nature of its association with ADA.

Human kidney ADA-binding protein was purified to apparent homogeneity by a two-step process $^{16}$. As shown in Table 2, the binding protein was purified approximately 1,700 -fold from crude kidney extract to a specific activity of 108 units of large form ADA activity/mg protein. The use of an affinity column containing calf ADA bound to polyacrylamide beads proved to be both a convenient and highly specific step in this purification. Since human small form and calf small form ADA were found to bind equally well to human ADAbinding protein, it was possible to use the calf enzyme for affinity purification of human binding protein. This was fortuitous since calf ADA was found to be more stable than the purified human small form enzyme and further could be obtained commercially in relatively pure form at low cost.

Analysis of the highly purified ADA-binding protein by native polyacrylamide gel electrophoresis revealed one protein band by Coomassie stain (Fig. 2A) coincident with ADA-binding protein activity as determined by assay of a companion gel (data not shown). SDS-polyacrylamide gel electrophoresis of purified ADA-binding protein also revealed only one protein band by Coomassie stain (Fig.
2B) with a calculated subunit molecular weight of 106,000 .

The purified ADA-binding protein was shown to have a native molecular weight of 213,000 by sedimentation equilibrium analysis ${ }^{15}$ and based on its subunit molecular weight appeared to be a dimer of identical subunits ${ }^{16}$. In addition, an SDS-polyacrylamide gel stained positive with the periodic acid-Schiff method and fluorescent dansylhydrazine, suggesting the presence of carbohydrate on the molecule (Fig. 2C). The
A. Native

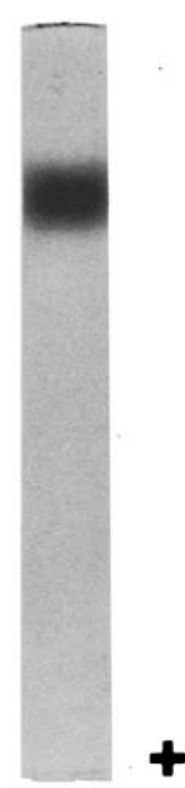

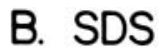

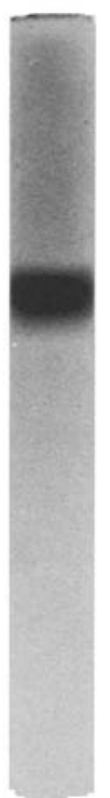

C. SDS

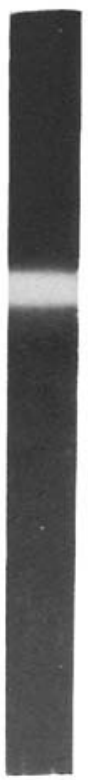

Fig. 2. Polyacrylamide gel electrophoresis of purified ADAbinding protein. A. Native $5 \%$ polyacrylamide gel, $\mathrm{pH} 8.3$ stained with Coomassie blue. B. SDS- $5 \%$ polyacrylamide gel stained with Coomassie blue. C. SDS- $5 \%$ polyacrylamide gel stained with periodic acid-Schiff reagent using dansylhydrazine (from reference 16). 
nature of the carbohydrate moiety of human kidney ADA-binding protein was further analyzed using a variety of lectins. The highly pure ADA-binding protein was found to react specifically only with the lectins, ricin and phytohemagglutinin, suggesting an internal linkage of $\beta$-galactose- $\beta$-N-acetyl galactose in the carbohydrate portion of the molecule. Failure of the kidney ADA-binding protein to react with the lectin, wheat germ agglutinin, suggested that sialic acid residues were not present on the molecule.

On several occasions we have also found that electrophoresis of purified ADA-binding protein on $5 \%$ SDS polyacrylamide gels revealed 2 subunit molecular weight species of 106,000 and 94,000 when stained for protein with Coomassie $^{16}$. The appearance of this lower subunit molecular weight species has also been observed on $5 \%$ SDS gels after storage of the native protein for several weeks at $4^{\circ}$. When a companion SDS gel was stained for carbohydrate, it was found that the lower subunit molecular weight species of the ADA-binding protein was markedly deficient in carbohydrate content suggesting that it was most probably a degradation product of the higher subunit molecular weight species. However, purified ADA-binding protein preparations were found to be free of detectable glycosidase activities indicating that this degradation mechanism may be non-catalytic.

SCHRADER et al. ${ }^{17}$, using a purification method similar to ours, have also reported purified ADA-binding protein (termed complexing protein) to be a dimer of native molecular weight 200,000 with subunit molecular weights estimated to be 97,000 and 85,000 .

\section{Stoichiometry of the Large Form Complex}

The studies cited above established that the large form ADA was composed of small form ADA and the ADA-binding protein. An analysis of the stoichiometry of the large molecular form of ADA (the ADA-binding protein complex) was performed in our laboratory using several different methods including direct binding, chemical cross-linking and sedimentation equilibrium analyses ${ }^{15}$.

The stoichiometry of the large form ADA was first analyzed by direct binding experiments.
The extent of binding between ${ }^{125}$ I-labeled small form ADA and varying amounts of purified binding protein could be followed conveniently by separation of the substrates and product of the binding reaction on polyacrylamide gels followed by quantitation of gel segments by gamma counting ${ }^{15}$. The binding reaction between small form $\mathrm{ADA}$ and binding protein was found to be complete within $10 \mathrm{~min}$. at $37^{\circ} \mathrm{C}$, to proceed over a broad $\mathrm{pH}$ range of 5 to 8 and to be unaffected by changes in ionic strength $(0-200 \mathrm{~mm} \mathrm{KCl})$, azide $(0.02 \%)$, thiols $(5 \mathrm{~mm})$, divalent metal ions (5 mM) and bovine serum albumin (1$25 \mathrm{mg} / \mathrm{ml})^{14,15}$. Various purine nucleosides and nucleotides including adenosine, inosine, AMP, IMP, GMP, cAMP, ATP, cGMP and GTP at various concentrations had no apparent effect on the binding reaction ${ }^{14}$. As shown in Figure 3, a Scatchard-type plot of our direct binding data indicated that 2.15 moles of small form ADA were bound to 1 mole of binding protein under the conditions of our assay.

Chemical cross-linking was used as another approach to determine the stoichiometry of large form ADA. Successful chemical crosslinking of large form ADA was dependent upon both the accessibility of the reactive groups on the component subunits of the native protein and the ability of the bifunctional cross-linking reagent to bridge between these reactive groups on adjacent subunits. If both conditions were satisfied, then the number of cross-linked species produced for large form ADA should theoretically equal the maximum number of different combinations of its subunits.

If large form ADA was composed of 2 moles of the monomeric small form ADA (designated $\mathrm{A}, \mathrm{A})$ and 1 mole of the dimeric binding protein (designated $\mathrm{BB}$ ), then 8 possible cross-linked combinations would be theoretically possible: BBAA, BBA, BAA, BB, BA, B, AA and A. Two types of radiolabeled native large form ADA were prepared by either combining ${ }^{125} \mathrm{I}-$ labeled ADA with non-labeled binding protein or by combining ${ }^{125}$ I-labeled binding protein with non-labeled ADA. When these ${ }^{125}$ I-labeled native large form ADA molecules were individually cross-linked with glutaraldehyde and electrophoresed on SDS polyacrylamide gels, the combined data consistently showed 6 different radioactive peaks (see Figure 4). With 


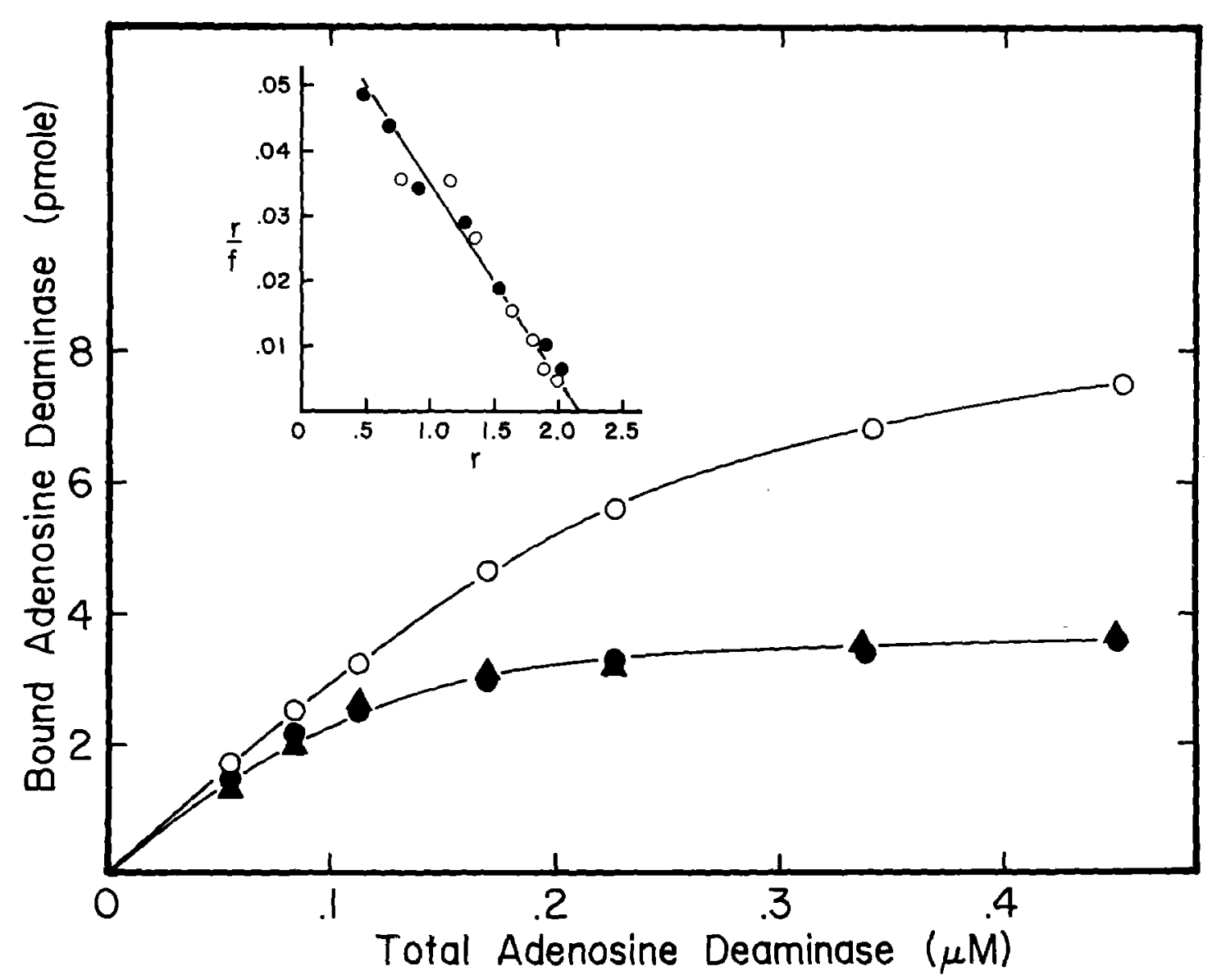

Fig. 3. Direct binding of small form ADA to ADA-binding protein. Highly purified binding protein $(0.05 \mu \mathrm{M}, 0-0.10 \mu \mathrm{M}$, $\mathrm{O}-\mathrm{O})$ was added to ${ }^{125} \mathrm{I}$-small form ADA $\left(3.6 \times 10^{9} \mathrm{dpm} / \mathrm{pmol}\right)$ diluted serially from $0.45 \mu \mathrm{M} .{ }^{125} \mathrm{I}$-small form ADA $\left(1.8 \times 10^{9} \mathrm{dpm} / \mathrm{pmol}\right)$ prepared by dilution with nonradioactive ADA, was also incubated with $0.05 \mu \mathrm{M}$ of highly purified binding protein ( $\mathbf{A}$ ) in a similar manner. The molecular weight of small form ADA and binding protein used in these calculations was assumed to be 38,000 and 213,000 , respectively, based on sedimentation equilibrium analyses data. The inset shows a Scatchard-type plot of the data in which $r$ is the number of moles of ADA bound per mole of binding protein and $f$ is the concentration of free ADA (from reference 15).

reference to authentic samples of binding protein and small form ADA, radioactive peaks observed at $\mathrm{Rf}=0.49$ and 0.31 corresponded to binding protein monomer $(\mathrm{B})$ and dimer $(\mathrm{BB})$, respectively, while the peak at $R f=0.88$ corresponded to monomeric small form ADA (A). The remaining radioactive peaks shown in Figure 4 observed at $\mathbf{R f}=0.40,0.27$ and 0.18 appeared to represent combinations of both binding protein and ADA subunits.

Since the mobility of each radioactive crosslinked species on SDS polyacrylamide gels should roughly correlate with its molecular weight, this relationship was used to limit the possible combinations of $A$ and $B$ subunits contained in the 3 coincident radioactive peaks present in Figure 4. The radioactive peak at $\mathrm{Rf}=0.40(\mathrm{Mr}=145,000)$ which migrated between binding protein monomer $(\mathrm{B}, \mathrm{Mr}=$ $106,000, \mathrm{Rf}=0.49)$ and $\operatorname{dimer}(\mathrm{BB}, \mathrm{Mr}=$ $213,000, R f=0.31$ ) would presumably be a $B A$ combination of expected molecular weight 144,000 . The peak at $\mathrm{Rf}=0.27(\mathrm{Mr}=250,000)$ present just after the binding protein dimer peak $(\mathrm{BB}, \mathrm{Mr}=213,000, \mathrm{Rf}=0.31)$, could possibly be a BBA combination of expected molecular weight 251,000 and finally the peak at $\mathrm{Rf}=0.18(\mathrm{Mr}=290,000)$ could reflect the cross-linked native complex, BBAA, of expected molecular weight 289,000 . A plot of the expected molecular weight for the proposed cross-linked species versus the log of their Rf 


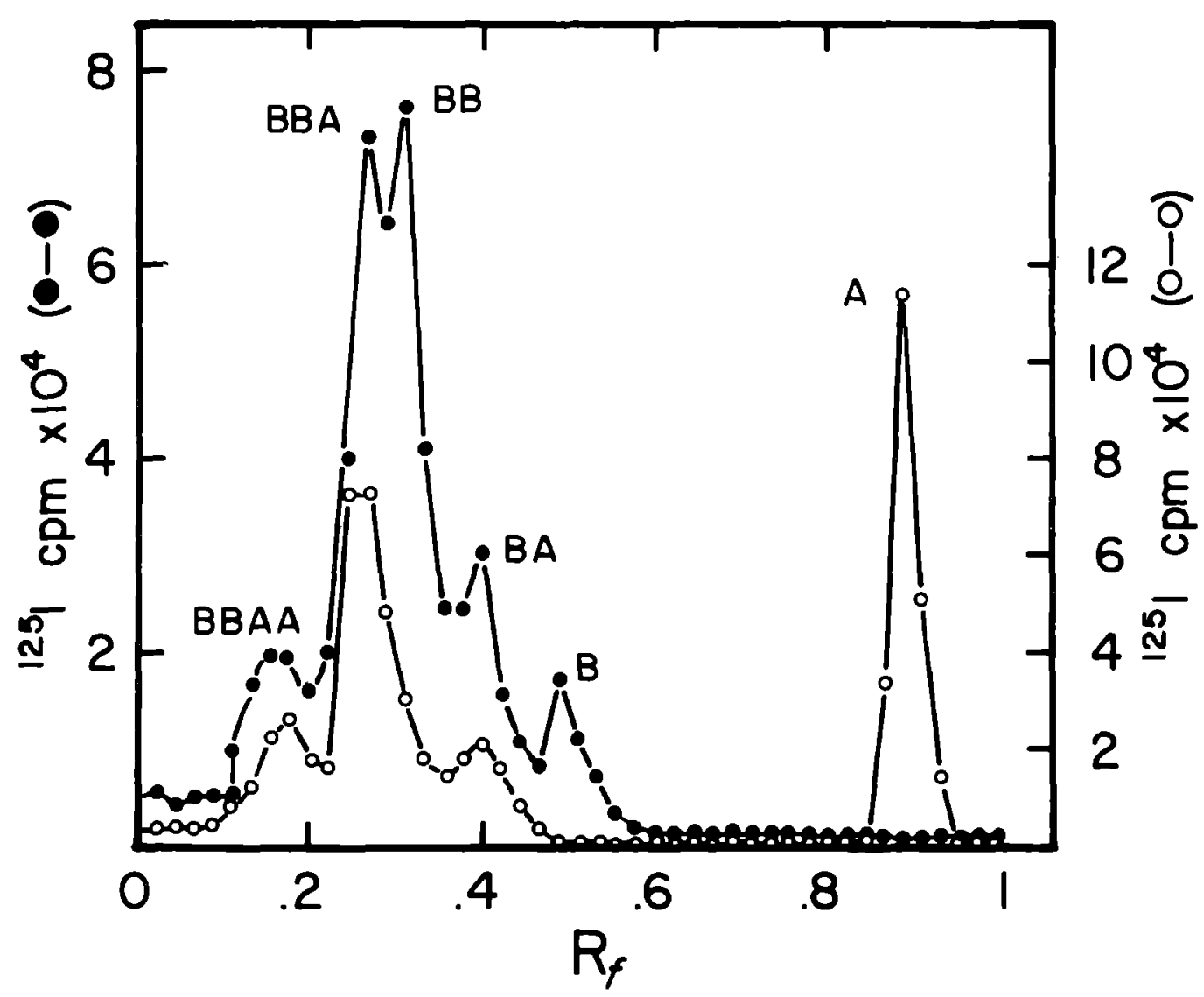

Fig. 4. SDS polyacrylamide gel profiles of cross-linked ${ }^{125}$ I-labeled large form ADA. Samples were cross-linked individually with glutaraldehyde for $1 \frac{1}{2} \mathrm{~h}$ and electrophoresed on 3-10\% linear gradient cylindrical SDS polyacrylamide gels. Gels were sliced into $1.5 \mathrm{~mm}$ sections and analyzed for ${ }^{125} \mathrm{I}$ radioactivity: Cross-linked large form ADA prepared with ${ }^{125} \mathrm{I}$ labeled ADA subunits $(\mathrm{O}-\mathrm{O})$ and cross linked large form ADA prepared with ${ }^{125} \mathrm{I}$ labeled binding protein subunits $(-)$ are shown. The putative cross-linked species are indicated by the appropriate letter abbreviations (from reference 15 ).

values was found to be linear. Noticeably absent in the radioactive gel profile were peaks corresponding to an AA species and a BAA species. This suggested that the distance between the two $\operatorname{ADA}(\mathrm{A})$ subunits in the native large form ADA molecule was too great for successful cross-linking under these conditions. If the stoichiometry of large form ADA were 1 mole of small form $\mathrm{ADA}$ and 1 mole of binding protein, then 5 cross-linked combinations of the subunits would theoretically be possible: BBA, $\mathrm{BB}, \mathrm{BA}, \mathrm{B}$ and $\mathrm{A}$. Our data clearly showed more cross-linking than this $1: 1$ model would predict and thus strongly favored a minimum $2: 1$ stoichiometry.

Sedimentation equilibrium analyses revealed a molecular weight of 300,000 for large form ADA (the ADA-binding protein complex). This molecular weight considered with molecular weights of 37,500 for small form ADA and
213,000 for binding protein, would be most consistent with the proposed stoichiometry of 2 moles of small form ADA and 1 mole of binding protein for the large form complex. The model for the association of small form ADA and the ADA-binding protein to produce the large form $\mathrm{ADA}$ is depicted in Figure 5 and indicates our current understanding of both the stoichiometry of large form ADA and its apparent symmetry.

The molecular weight of the large form ADA prepared in vitro in our experiments compared well with previous estimates of the large form ADA molecular weight analyzed from several different tissue sources ${ }^{14}$. This suggested that the stoichiometry of the large form ADA complex may be constant regardless of the tissue source of the enzyme or the "tissue specific" isozyme present. It has been proposed by Swallow et al. ${ }^{18}$ that the "tissue specific" 

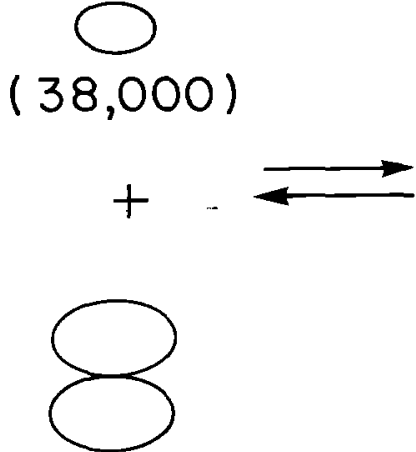

$(213,000)$

Fig. 5. Proposed model for the formation of the large molecular form of ADA. Based on direct binding experiments and sedimentation equilibrium analyses, it appears that 2 moles of monomeric small form $\mathrm{ADA}(\mathrm{Mr}=38,000)$ combine with 1 mole of the dimeric ADA-binding protein $(\mathrm{Mr}=213,000)$ to produce 1 mole of the large form ADA complex $(\mathrm{Mr}=300,000)$. Scatchard analysis and chemical cross-linking indicates that the binding protein has only one small form ADA binding site per subunit and that these binding sites are apparently non-interacting and geometrically distance from one another. With a calculated dissociation constant $(\mathrm{Kd})$ of $2.8 \times 10^{-8} \mathrm{M}$, the large form ADA complex may dissociate spontaneously at low physiological concentrations to produce the small form of the enzyme and the ADA-binding protein.

isozymes of large form ADA may reflect the association of the small form ADA with a "tissue specific" ADA-binding protein of heterogeneous carbohydrate content. It has been suggested that probably the sialic acid content of the binding protein present in a given tissue may contribute to the electrophoretic properties of the corresponding large form ADA produced; however, it should be noted that treatment of tissue extracts with neuraminidase does not alter the molecular form or molecular weight of the large form complex $^{18}$.

Although we have characterized the physical and chemical properties of ADA and its binding protein in some detail, at present the physiological significance of this association still remains obscure. Our early observation of an inverse relationship between the specific activity of ADA in crude tissue extracts and the concentration of the ADA-binding protein suggested a possible inhibitory or regulatory function for the binding protein ${ }^{14}$. However using purified fractions, the interaction of binding protein with small form ADA did not appear to alter the kinetic properties of the enzyme i.e., the Vmax,
$\mathrm{Km}$ for adenosine, and $\mathrm{Ki}$ for inosine remain identical even in the presence of a 100 -fold molar excess of the binding protein ${ }^{16}$. While the ADA-binding protein does not appear to directly affect the kinetic properties of ADA, the possibility still exists that the binding protein may regulate the level of ADA activity in vivo. In a given tissue, the "tissue specific" ADAbinding protein(s) may function by either altering the rate of synthesis and/or degradation or by influencing the intra-cellular location and/or intracellular transport of ADA. All of these possibilities, however, remain to be examined. Alternatively or in addition, the possibility also exists that ADA might be regulating a still to be defined function(s) of the binding protein. Based on a literature search for proteins with similar physical characteristics to our ADA-binding protein, the enzyme S-adenosylhomocysteine hydrolase (EC3.3.1.1) appeared as an interesting candidate for our ADA-binding protein. This enzyme has been shown to be required for the hydrolysis of S-adenosylhomocysteine to produce adenosine and homocysteine ${ }^{19}$. Since S-adenosylhomocysteine hydrolase (also termed the adenosine binding protein) is strongly inhibited by adenosine, the hydrolysis reaction in vivo would be highly dependent upon the removal of adenosine by $\mathrm{ADA}$. Thus an association between these two enzymes would be logical. We have monitored the activity of S-adenosylhomocysteine hydrolase and our ADA-binding protein through the purification scheme of binding protein in human kidney and found unfortunately that both activities were separate and distinct ${ }^{20}$.

We have also begun to search in other directions to try to establish the identity and/or function of the ADA-binding protein. We have observed that human serum contains predominantly the large molecular form of ADA and that detectable binding protein activity is also present $^{20}$. This finding coupled with the recent observation that the human ADA binding protein is coded for on chromosome $6^{21}$ led us to speculate that binding protein might be related to one of the HLA antigens or might have some intrinsic immunoregulatory function. Therefore, in preliminary experiments, we have begun to assess the affects of binding protein on lymphocyte function. In our initial studies, we have been unable to detect any inhibition or other 
effects on PHA stimulation of lymphocytes in the presence of binding protein concentrations as high as 100 times the level normally found in serum $^{20}$. However, further experiments in this direction are in progress.

We have also tried to determine whether the ADA-binding protein might associate with some other human tissue proteins in addition to ADA. This possibility was tested by two different techniques. First, using a column containing binding protein attached to Sepharose, we established that ADA could be bound and detected. Then various human tissue extracts were individually passed through the column e.g., spleen, kidney, stomach, and small intestine. The column was then washed, eluted with urea and the eluate analyzed by SDSpolyacrylamide gel electrophoresis. Within the sensitivity of this method, no protein other than small form ADA appeared to associate with binding protein coupled to the column. Using an alternative approach, ${ }^{125}$ I-labeled binding protein was incubated with an individual tissue extract and the mixture resolved by either sucrose gradient ultracentrifugation or Sephadex G-200 column chromatography. Again using tissue extracts of spleen, kidney, stomach and small intestine only radioactive peaks corresponding to binding protein or large form ADA (ADA-binding protein complex) could be detected, confirming the specificity of the ADA binding protein ${ }^{20}$.

\section{Characteristics of Residual Adenosine Deaminase in Patients with Severe Combined Immunodeficiency Disease}

A deficiency of ADA associated with an autosomal recessive form of severe combined immunodeficiency disease (SCID) has been described in well over 30 patients since the initial report by GIBLETT et al. in $1972^{1}$. In all cases the patients exhibited virtually no enzyme activity in their erythrocytes although residual ADA activity has been observed in other tissues of these patients.

In an early report ${ }^{22}$, splenic tissue of a patient with SCID was found to have $0.5 \%$ or normal ADA activity. The striking finding in this case was that the moleular weight of this enzyme activity was 110,000 . At a later date, ScHRADER et $a .^{23}$ found that normal spleen also exhibited a similar if not identical adenosine deaminating enzyme of $\mathrm{Mr}=110,000$. On the basis of immunochemical analysis, sensitivity to the competitive ADA inhibitor erythrohydroxynonyl adenine (EHNA), Km, and $\mathrm{pH}$ optimum, it was shown that this aminohydrolase was clearly distinct from normal splenic ADA.

Several studies have suggested that ADA may be structurally altered in some patients with this enzyme deficiency. Cultured skin fibroblasts from two different patients with SCID revealed approximately $1 \%$ and $10 \%$ of normal ADA activity $^{24}$. In the latter case, the $\mathrm{pH}$ optimum and $\mathrm{Km}$ appeared normal, but the enzyme exhibited altered electrophoretic mobility and increased heat stability. In another study, the fibroblast cell strains from four different immunodeficient patients were found to have about $20 \%$ of normal ADA activity and a normal $\mathrm{Km}$ for adenosine, however again the enzyme activity in these cell strains demonstrated altered electrophoretic mobility and increased heat stability suggesting an altered enzyme structure ${ }^{25}$.

In a limited study of three ADA deficient fibroblast cell strains, an immunoassay for ADA revealed that one cell strain with trace $\mathrm{ADA}$ activity had immunoreactive protein (CRM) at a level approximately $35 \%$ of normal while two other ADA deficient cell strains with less than $1 \%$ enzymatic activity demonstrated less than $5 \%$ of normal $\mathrm{CRM}^{26}$. In this study however, it could not be excluded with certainty that fetal calf ADA in the fibroblast culture media may not have been endocytosed by at least one of these cell strains.

In order to more accurately evaluate the genetic expression of ADA in this immune disorder, we have developed a specific radioimmunoassay for ADA capable of detecting as little as $0.06 \%$ of normal CRM. We have used this radioimunoassay and an equally sensitive ADA enzymatic assay for the analysis of hemolysate samples from 9 heterozygote parents and 4 unrelated children with ADA deficiency and $\mathrm{SCID}^{27}$.

Table 3 shows the characteristics of erythrocyte ADA in hemolysates from normal, heterozygous and homozygous deficient subjects. ADA activity for 18 normal adults and 5 normal children was found to be $0.88 \pm 0.25$ and 
Table 3

Characterization of erythrocyte adenosine deaminase

\begin{tabular}{lccc}
\hline Hemolysate* & $\begin{array}{c}\text { Sp. Act. } \\
\text { nmol/min/mg }\end{array}$ & ng CRM/mg & $\begin{array}{c}\text { Abs. Sp. Act. } \\
\mu \text { mol } / \mathrm{min} / \mathrm{mg} \text { CRM }\end{array}$ \\
Normal & $0.88 \pm 0.24^{* *}$ & $1.67 \pm 0.60$ & $563 \pm 46$ \\
Adults (18) & $(0.53-1.20)$ & $(0.90-2.23)$ & $(531-620)$ \\
Normal & $0.86 \pm 0.26$ & $1.55 \pm 0.50$ & $553 \pm 14$ \\
Children (5) & $(0.62-1.20)$ & $(1.07-2.22)$ & $(540-572)$ \\
& & & 562 \\
Heterozygote & 1.35 & 2.40 & 537 \\
R.M. & 0.29 & 0.54 & 500 \\
D.M. & 0.74 & 1.47 & 448 \\
T.T. & 0.56 & 1.25 & 586 \\
E.B. & 0.68 & 1.16 & 569 \\
La.L. & 0.41 & 0.72 & 595 \\
L.L. & 0.56 & 0.94 & 535 \\
M.H. & 0.60 & 1.12 & 320 \\
F.H. & 0.33 & 1.02 & - \\
R.W. & $<0.8 \times 10^{-3}$ & & - \\
Homozygote & $<0.8 \times 10^{-3}$ & $<0.001$ & - \\
R.M., Jr. & $<0.8 \times 10^{-3}$ & 0.007 & - \\
B.W. & $<0.8 \times 10^{-3}$ & 0.052 & -087 \\
E.M. & & 0.087 & \\
M.H. & & & \\
\hline
\end{tabular}

* Protein concentrations for hemolysates ranged from $287-156 \mathrm{mg} / \mathrm{ml}$.

$* *$ Mean \pm 1 S.D., range given in parenthesis.

(from Reference 27).

$0.86 \pm 0.26 \mathrm{nmol} / \mathrm{min} / \mathrm{mg}$ hemolysate protein, respectively. Using the radioimmunoassay, the quantity of ADA immunoreactive protein (CRM) was determined to be $1.67 \pm 0.60$ and $1.55 \pm 0.50 \mathrm{ng} \mathrm{CRM} / \mathrm{mg}$ hemolysate protein and the mean absolute specific activity was calculated to be $563 \pm 46$ and $553 \pm 14 \mu \mathrm{mol} / \mathrm{min} / \mathrm{mg}$ CRM for normal adults and children, respectively. The calculated absolute specific activities compared well with the value of $538 \mu \mathrm{mol} / \mathrm{min} / \mathrm{mg}$ previously reported for homogeneous erythrocyte $\mathrm{ADA}^{8}$. The close agreement between the calculated and authentic absolute specific activity of ADA provided further evidence for the accuracy of our radioimmunoassay used in conjunction with the ADA enzymatic assay and confirmed the absense of systematic error.

As noted in Table $3, \mathrm{ADA}$ enzymatic activity varied substantially from $0.53-$

$1.20 \mathrm{nmol} / \mathrm{min} / \mathrm{mg}$ hemolysate protein as did the level of ADA CRM (0.9-2.23 ng/mg hemolysate protein) for the 18 normal adult hemolysates analyzed. However, the level of enzyme activity and CRM for each sample showed a good correlation suggesting that the catalytic activity per molecule of ADA was similar while the concentration of ADA varied in each of the normal hemolysate samples.

The specific activity of ADA in the hemolysates of the heterozygous parents ranged from 0.29 to $1.35 \mathrm{nmol} / \mathrm{min} / \mathrm{mg}$ with several samples falling within the normal adult range while the quantity of ADA CRM among these samples also showed a wide range (Table 3). However, the calculated absolute specific activity for ADA $(\mu \mathrm{mol} / \mathrm{min} / \mathrm{mg} \mathrm{CRM})$ in the majority of hemolysates from heterozygotes appeared to fall within the normal range. Samples E.B., T.T. and R.W. were the exceptions with calculated absolute specific activities at least 1 S.D. below the normal adult mean. CRM in these three heterozygote hemolysates showed the same affinity toward ADA antibody as did the normal erythrocyte enzyme. Further analysis of the ADA from these subjects revealed a normal $\mathrm{Km}$ for adenosine and complete inhibition of enzyme activity in the presence of the competitive enzyme inhibitor erythrohydroxynonyl adenine (EHNA). 
Variable genetic expression of the "silent" or apparently defective ADA allele(s) was even more apparent in the hemolysate of the homozygous deficient subjects. The hemolysates from homozygous ADA deficient subjects all showed undetectable enzyme activity of $<0.09 \%$ of the normal mean activity (representing the lower limit of our enzymatic assay) (Table 3). Enzyme activity resulting from mixing normal and ADA deficient hemolysate was additive, suggesting the absence of an ADA inhibitor in these samples.

The hemolysate of R.M. Jr., the child of D.M. and R.M., failed to exhibit any detectable CRM, i.e., less than $0.06 \%$ of mean CRM for normal children, consistent with the calculation of a normal absolute specific activity for ADA in the hemolysate of both parents (R.M. and D.M.). In this family, the data suggested that only the "normal" ADA allele was expressed in the hemolysate of the parents while the inherited "silent" or defective allele from both parents did not produce a gene product immunologically detectable by this antiserum or alternatively produced a gene product which may have been rapidly degraded in vivo. The hemolysates of B.W., E.M. and M.H., however, all had easily detectable quantities of ADA CRM ranging from $0.4 \%$ to $5.6 \%$ of the normal child mean CRM.

From this limited number of samples, heterozygous and homozygous hemolysates from 5 of the 8 total families analyzed revealed apparent variable genetic expression of the "silent" or defective ADA allele(s). Further, hemolysate from some heterozygous subjects had quantities of the normal gene product which brought total enzyme quantities to a normal mean level suggesting possible autologous regulation of $\mathrm{ADA}$ in the reticulocytes of these subjects.

Further studies on the nature of the genetic defect associated with ADA deficiency should involve detailed structural analysis of the enzyme gene product. In cases that permit, purification and peptide mapping of the mutant forms of ADA could provide the first direct evidence for a structural defect in the primary sequence of the ADA molecule. In addition, analysis of the rate of synthesis and degradation of the enzyme in normal and ADA deficient fibroblast or lymphoblast cell lines might allow a better understanding of the observed variable levels of the enzyme noted among different subjects and might establish the intriguing possibility of a distinct regulatory gene for ADA.

\section{References}

1. Giblett, E. R., Anderson, J. E., Cohen, F., Pollara, B. and Meuwissen, H. J., 1972. Lancet 2, 1067-1069.

2. Dissing, J. and Knudsen, B., 1972. Lancet 2, 1316.

3. Parkman, R., Gelfand, E. W., Rosen, F. S., Sanderson, A. and Hirschorn, R., 1975. New Eng. J. Med. 292, 714-719.

4. Meuwissen, H. J., Pollara, B. and Pickering, R. J. (1975) J. Pediatrics 86, 169-181.

5. Spencer, N., Hopkinson, D. A., and Harris, H., 1968. Ann. Hum. Genet. 32, 9-14.

6. Osborne, W. R. A. and Spencer, N., 1973. Biochem. J. 133, 117-123.

7. Schrader, W. P., Stacy, A. R. and Pollara, B., 1976. J. Biol. Chem. 251, 4026-4032.

8. Daddona, P. E. and Kelley, W. N., 1977. J. Biol. Chem. 252, 110-115.

9. Edwards, Y. H., Hopkinson, D. A. and Harris, H., 1971. Ann. Hum. Genet. 35, 207-219.

10. Nishihara, H., Ishikawa, S., Shinkai, K. and Akedo, H., 1973. Biochem. Biophys. Acta. 302, 429-442.

11. Hirschhorn, R., Levytska, V., Meuwissen, H. J. and Pollara, B., 1973. Nature New Biol. 246, 200-202.

12. Creagan, R. P., Tischfield, J. A., Nichols, E. A., and Ruddle, F. H., 1973. Lancet, 1449-1450.

13. Hirschhorn, R., 1975. J. Clin. Invest. 55, 661-667.

14. Van der Weyden, M. B. and Kelley, W. N., 1976. J. Biol. Chem. 251, 5448-5456.

15. Daddona, P. E. and Kelley, W. N., 1979. Biochem. Biophys. Acta in press.

16. Daddona, P. E. and Kelley, W. N., 1978. J. Biol. Chem. $253,4617-4623$.

17. Schrader, W. P. and Stacy, A. R. (1977) J. Biol. Chem. 252, 6409-6415.

18. Swallow, D. M., Evans, L. and Hopkinson, D. A., 1977. Nature 269, 261-262.

19. De La Haba, G. and Cantoni, G. L., 1959. J. Biol. Chem. 234, 603-608.

20. Daddona, P. E. and Kelley, W. N., 1979. Unpublished observations.

21. Koch, G. and Shows, T. B., 1978. Proc. Natl. Acad. Sci. 75, 3876-3878.

22. Van der Weyden, M. B., Buckley, R. H., and Kelley, W. N., 1974. Biochem. Biophys. Res. Commun. 57, 590-595.

23. Schrader, W. P., Pollara, B. and Meuwissen, H. J., 1978. Proc. Natl. Acad. Sci. 75, 446-450.

24. Chen, S. H., Scott, C. R. and Swedberg, K. R., 1975. Am. J. Hum. Genet. 27, 46-53.

25. Hirschhorn, R., Beratis, N. and Rosen, F. S., 1976 Proc. Natl. Acad. Sci. 73, 213-217.

26. Carson, D. A., Goldblum, R. and Seegmiller, J. E., 1977. J. Immunol. 118, 270-273.

27. Daddona, P. E., Frohman, M. A. and Kelley, W. N., 1979. J. Clin. Invest. 64, 798-803. 